ISSN 1392-3196 / e-ISSN 2335-8947

Zemdirbyste-Agriculture, vol. 102, No. 1 (2015), p. 73-80

DOI 10.13080/z-a.2015.102.009

\title{
Spatial distribution patterns of apple sawfly populations in two differently managed commercial apple orchards
}

\author{
Rimantas TAMOŠIŪNAS ${ }^{1}$, Alma VALIUŠKAITE ${ }^{1}$, Laurynas JUKNA², \\ Kęstutis TAMOŠIŪNAS ${ }^{3}$, Algimantas Feliksas ŽIOGAS ${ }^{4}$ \\ 'Institute of Horticulture, Lithuanian Research Centre for Agriculture and Forestry \\ Kauno 30, Babtai, Kaunas distr., Lithuania \\ E-mail: rimantas@mkds.lt \\ ${ }^{2}$ Vilnius University \\ Čiurlionio 21/27, Vilnius, Lithuania \\ ${ }^{3}$ Institute of Agriculture, Lithuanian Research Centre for Agriculture and Forestry \\ Instituto 1, Akademija, Kedainiai distr., Lithuania \\ ${ }^{4}$ Institute of Biology and Plant Biotechnology, Aleksandras Stulginskis University \\ Studentų 11, Akademija, Kaunas distr., Lithuania
}

\begin{abstract}
An investigation on spatial distribution of apple sawfly (Hoplocampa testudinea Klug, 1816) populations was conducted in organically and conventionally managed apple orchards of Institute of Horticulture, Lithuanian Research Centre for Agriculture and Forestry in 2010-2013. The aim of this study was to examine population density patterns of within orchard spatial distribution of apple sawfly. White sticky traps Rebell ${ }^{\mathbb{B}}$ bianco (Andermatt Biocontrol, Switzerland) were used to monitor apple sawfly population density. In order to determine aggregation extent in sawfly populations, coefficient $k$ of the negative binomial distribution, serving as aggregation index, was computed using maximum-likelihood method. Additionally, in order to accurately evaluate distribution patterns of apple sawfly within orchards, spatial analysis using Kernel density function was performed. Spatial analysis was performed using program package ARCGIS 10. Results of the study on spatial distribution patterns of apple sawfly imagoes demonstrated strong tendency for aggregation of adult sawflies across the orchard area. Localisation of clumps was quite constant despite the size of the orchard. Such knowledge could be applied for optimization of apple sawfly control strategies, especially in large orchards. The highest infestation levels were recorded exactly in the aggregations of sawflies over the course of the study. Moreover, knowing exact locations of such aggregations could be useful for optimization of positioning of traps in the orchards and, ultimately, restricting insecticide applications only to places where it is really necessary.
\end{abstract}

Key words: apple fruit pests, geographic information systems, Hoplocampa testudinea, integrated pest management, Kernel density, spatial distribution.

\section{Introduction}

Apple sawfly (Hoplocampa testudinea Klug (Hymenoptera, Symphyta, Tenthredinidae)) is a serious and widespread pest of apple fruits that causes heavy losses for fruit-growers in every region where apple is cultivated (Ciglar, Barić, 2002; Taeger et al., 2006; Roller, Haris, 2008; Walczak et al., 2009; van Achterberg, 2013). Former studies indicated that this species caused significant damage to apple yield in Lithuania in the late $20^{\text {th }}$ century (Raudonis, 1997). However, at that time the setup of apple genotypes cultivated was completely different from that of apple genotypes grown in conventional apple orchards at present time.

Control of apple sawfly is mostly achieved through the use of synthetic or biological pesticides. In Lithuanian commercial apple orchards, sawfly control strategies are based mostly on non-selective insecticide treatments. According to the requirements of these management strategies, the use of synthetic pesticides must be greatly reduced. As a result, rational integrated management tactics are needed, which include optimal timing of insecticide treatments, justification for the necessity of their use against apple sawfly and precise application in the portions of the orchards where aggregations of the target pest are the highest. This could maximize efficiency of treatments and minimize the impact on the environment and crop safety. A shift towards integrated pest management and development of organic fruit farming poses new challenges to apple growers and plant protection specialists. So far, various means have been developed for optimization of apple sawfly management. Several tools for predicting the spring emergence of adult sawflies (Graf et al., 1996 a; Zijp, 
Blommers, 1997; Tamošiūnas, Valiuškaite, 2013), life span and egg-laying time (Graf et al., 2001), embryonic development duration and egg-hatch (Ciglar, Barić, 2002; Graf et al., 2002; Falta, Kneifl, 2006) were developed. White sticky traps were investigated and proposed as a valuable and reliable tool for monitoring apple sawfly population dynamics and infestation prognosis (Wildbolz, Staub, 1984; Galli et al., 1993; Graf et al., 1996 b), economic damage threshold was determined under western Germany, Swiss and Lithuanian conditions (Wildbolz, Staub, 1984; Graf et al., 1996 b; Tamošiūnas et al., 2014).

In ecological studies of insect populations attention is mainly focused on distribution and density changes in time. This data provides valuable information about processes working in insect populations. Nonetheless, valuable information can be obtained by analyzing spatial distribution patterns of insects in the population. Various indices, such as $k$ of the negative binomial, Iwao's (1968) "patchiness" index, Taylor's (1984) power law coefficient $b$ or Lloyd's (1967) mean crowding index are used to evaluate different aspects of insect distribution. In order to develop a reasonable apple sawfly integrated control strategy, it is important to determine spatial distribution patterns of these insects in orchards. Although indices of aggregation are useful criteria indicating population distribution patterns, they also have drawbacks - differences between spatial distribution models cannot be determined using these indices as they are strongly dependent on the scale of sample units as was described in the model of Jumars et al. (1977) and indicated by Sawyer (1989).

In the last few decades with a rapid development of GIS (geographic information systems) technologies, appropriate GIS tools suitable for spatial analysis of insect populations and possibility to apply these results for control of major agricultural pests have become available (Carriére et al., 2006). Indices mentioned before can provide useful insights about distribution of insect populations: tendency for randomness or aggregation. However, they cannot indicate distribution patterns depending on spatial position of sampling sites. By means of GIS technologies and geostatistical methods, distribution patterns of insect populations can be represented in a map and population density in certain location modelled. This information can later be used in the development of reasonable pest control strategies (Racca et al., 2010). In order to prepare rational integrated management tactics for apple sawfly, one of the steps is to know spatial distribution patterns of this pest in the orchards.

The aim of this study was to examine population density patterns of within orchard spatial distribution of apple sawfly.

\section{Materials and methods}

Experimental site of the field studies. The study was performed at experimental apple orchards of Institute of Horticulture, Lithuanian Research Centre for Agriculture and Forestry in Central Lithuania for four consecutive apple and plum seasons from 2010 to 2013. Apple sawfly populations were surveyed in two differently managed apple orchards - organic and conventional located approximately $0.7 \mathrm{~km}$ from each other (Fig. 1).

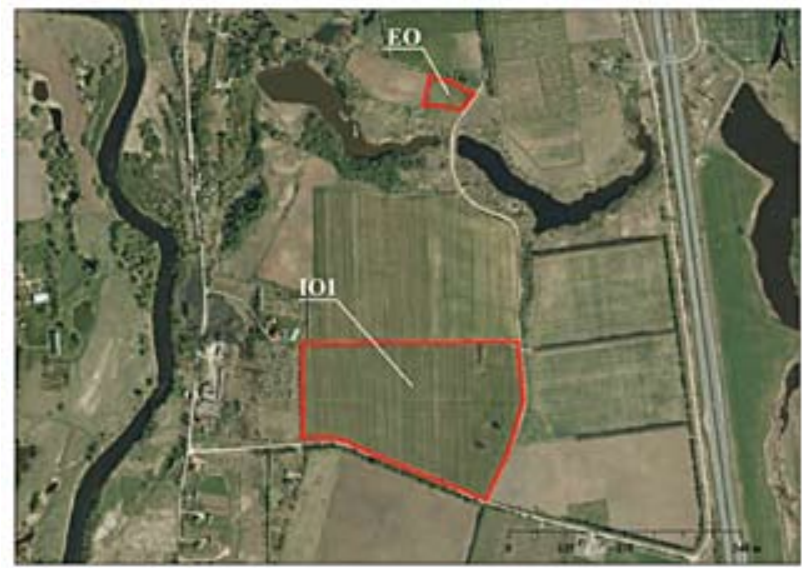

Figure 1. Experimental sites of organic (designated as EO) and conventional (designated as IO1) apple orchards (Babtai, Kaunas distr., 23.806720 ${ }^{\circ}$, 55.067072 ${ }^{\circ}$, WGS 1984), 2010-2013

Both orchards were separated by a valley and natural hedgerows of multi-species vegetation. Both were productive orchards, aged 6 (organic) and 8 (conventional) years in 2010. Rows were oriented in a south-north direction and planting distances were $4 \times$ $2 \mathrm{~m}$ (density 1250 trees $\mathrm{ha}^{-1}$ ), except for cv. 'Noris' and 'Ligol' grafted on rootstock P22 with planting distances $4 \times 1 \mathrm{~m}$ (density 2500 trees $\left.\mathrm{ha}^{-1}\right)$. Average height of trees in both orchards on was approximately $2.5 \mathrm{~m}$ and trees were shaped as a spindle canopy.

Conventionally managed orchard occupied an area of 13 ha and was comprised of different apple cultivars planted in two to four row blocks throughout the orchard. In the interrows of the orchard the mixture of couch grass was sown and grass in the alleys was regularly mown during the season. Herbicide treatments were applied on the grass below the trees several times during the season and herbicide fallow was $1 \mathrm{~m}$ wide. Fungicide treatments were applied regularly according to recommendations for plant pest and disease management in conventional orchards. The following pre-bloom insecticide treatments relevant to apple sawfly control were applied - in 2010 Decis Mega (a.i. deltamethrin) on 27 April, 2011 - Decis Mega (a.i. deltamethrin) on 29 April, 2012 - Bulldock (a.i. $\beta$-cyfluthrin) on 26 April and 2013 - Bulldock (a.i. $\beta$-cyfluthrin) on 4 May. Organic orchard occupied an area of $0.5 \mathrm{ha}$, where different apple cultivars were arranged in random order throughout the orchard in four repetitions per cultivar, each repetition plot consisting of four trees. Organic orchard was pesticide and artificial fertilizer-free since the moment it had been planted. Inter-rows were arranged in changing order where inter-row covered with grass was followed by shallow cultivated one. Grass in the alleys was repeatedly mown as well as alleys without grass were cultivated regularly. Apple genotypes (15 cultivars and 1 breeding kit) of regional economic importance for commercial and organic horticulture were selected for the survey (Table 1). All cultivars were moderately-late to late blooming, except breeding kit No. 18051. The latter was moderately-early blooming.

White sticky traps Rebell ${ }^{\circledR}$ bianco (Andermatt Biocontrol, Switzerland) were used to monitor apple sawfly flight activity and population density. Trap distribution and infestation sampling details in different cultivars are shown in Table 1 . In conventional orchard, 
Table 1. The experimental design of the study

\begin{tabular}{|c|c|c|c|c|c|c|c|c|c|}
\hline \multirow{2}{*}{ Cultivar } & \multirow{2}{*}{ Rootstock } & \multicolumn{2}{|c|}{2010} & \multicolumn{2}{|c|}{2011} & \multicolumn{2}{|c|}{2012} & \multicolumn{2}{|c|}{2013} \\
\hline & & sampled & traps & sampled & traps & sampled & traps & sampled & traps \\
\hline \multicolumn{10}{|c|}{ Conventional orchard } \\
\hline 1. 'Noris' & M26 & + & 1 & + & 4 & + & 4 & + & 4 \\
\hline 2. 'Lodel' & M26 & + & 1 & + & 4 & + & 4 & + & 4 \\
\hline 3. 'Ligol' & P2 & + & 2 & + & 4 & + & 4 & + & 4 \\
\hline 4. 'Auksis' & M26 & + & 3 & + & 4 & + & 4 & + & 4 \\
\hline 5. 'Delikates' & MM106 & + & 2 & + & 4 & + & 4 & + & 4 \\
\hline 6. 'Alva' & M26 & + & 3 & + & 4 & + & 4 & + & 4 \\
\hline 7. 'Spartan' & M26 & + & 1 & + & 4 & + & 4 & + & 4 \\
\hline 8. 'Lobo' & M26 & + & 2 & + & 4 & + & 4 & + & 4 \\
\hline 9. 'Connell Red' & M26 & + & 1 & + & 4 & + & 4 & + & 4 \\
\hline \multicolumn{10}{|c|}{ Organic orchard } \\
\hline 1. 'Rubinola' & B396 & + & 1 & + & 4 & + & 4 & + & 4 \\
\hline 2. 'Aldas' & B396 & + & 1 & + & 4 & + & 4 & + & 4 \\
\hline 3. Breeding kit. No. 18051 & B396 & + & 1 & + & 4 & + & 4 & + & 4 \\
\hline 4. 'Vitos' & B396 & + & 1 & + & 4 & + & 4 & + & 4 \\
\hline 5. 'Enterprise' & B396 & - & - & + & 4 & + & 4 & + & 4 \\
\hline 6. 'Lodel' & B396 & - & - & + & 4 & + & 4 & + & 4 \\
\hline 7. 'Rajka' & B396 & - & - & + & 4 & + & 4 & + & 4 \\
\hline
\end{tabular}

study plots consisted of two adjacent rows per each cultivar equipped with four equally distributed traps two being placed closer towards the end and two towards the centre of the rows at 30-50 m distances (Fig. 2). In organic orchard, traps were installed on each of four repetition plots per cultivar studied and distances between traps varied between 5-10 m (Fig. 3). Traps were hung on branches or supporting wires at the height of 1.6-1.7 $\mathrm{m}$ on the external south part of the tree canopy. The positions of traps remained unchanged during each year of the study. Sawfly population density was expressed as a relative measure based on mean number of sawflies captured per trap during certain time interval.

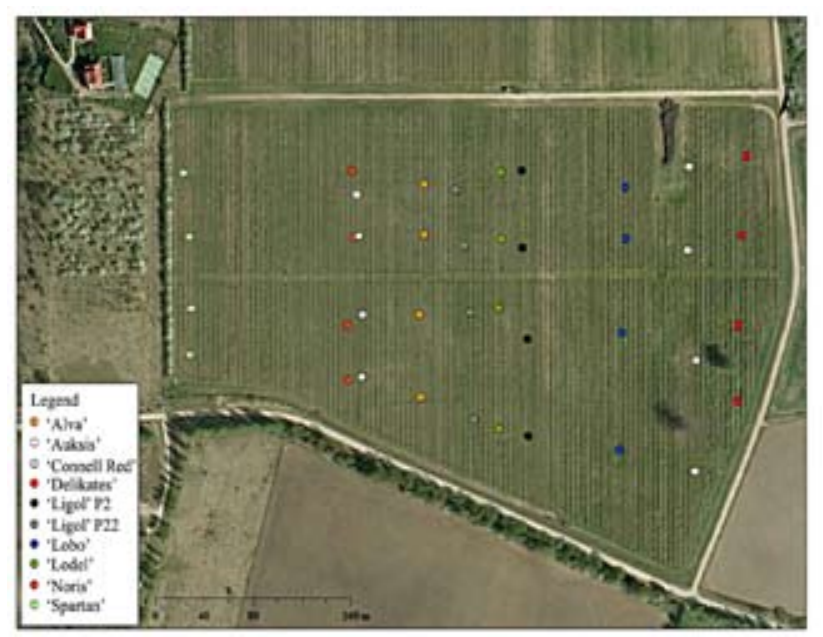

Figure 2. Trap and studied cultivar placement in the conventional apple orchard (Babtai, Kaunas distr.), 2011-2013

Each year of the survey, white sticky traps were introduced into the orchards two weeks before beginning of May. In order to determine the beginning of adult sawfly flight period, traps were inspected every two days. After catching the first sawflies, traps were checked once per week in 2010 and every 1-3 days in 2011-2012. Sawfly adults were counted and removed from the traps.

Statistical analysis. Adult sawfly trap catch data was not distributed normally. Since variances of

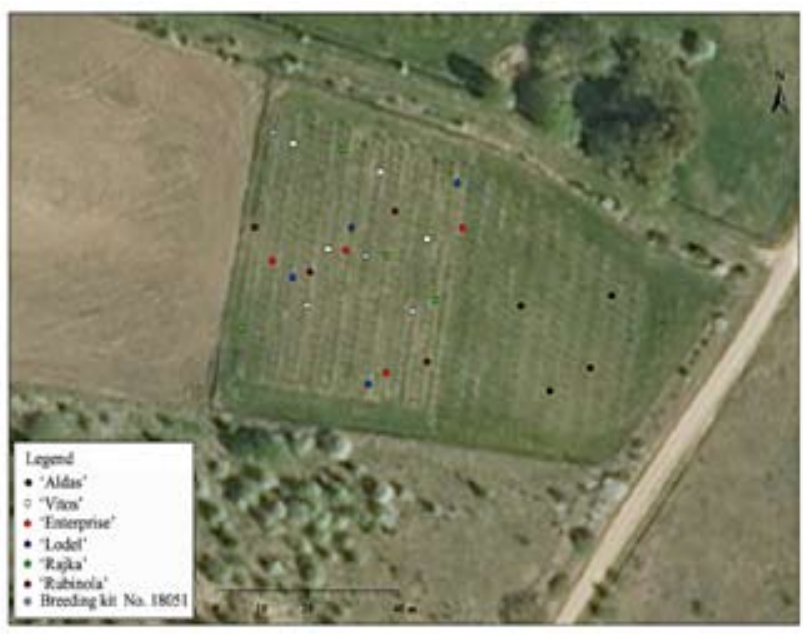

Figure 3. Trap and studied cultivar placement in the organic apple orchard (Babtai, Kaunas distr.), 2011-2013

trap catches were higher than the means, assumption that trap catch data could be fitted to negative binomial distribution was made. Goodness-of-fit to negative binomial was tested by means of Kolmogorov-Smirnov test (Zar, 2010). Normality of data was tested by means of Shapiro-Wilk test. Statistical routines were performed using program packages Systat and Sigmaplot.

In order to determine aggregation extent in sawfly populations, $k$ of the negative binomial, serving as aggregation index, was computed using maximumlikelihood method. Several $k$ were calculated for different orchards in different years.

The mean number of individuals in the aggregation was calculated using Arbous and Kerrich (1951) formula:

$$
\lambda=\frac{\bar{x}}{2 k} v
$$

where $v$ is a function with a $\chi^{2}$ distribution with $2 k$ degrees of freedom ( 0.5 probability level was used), $\lambda=$ the number of individuals in the aggregation for the probability level allocated to $v$. 
Additionally, in order to accurately evaluate distribution patterns of apple sawfly within orchards, spatial analysis using Kernel density function was performed. This function estimates relative density of individuals in certain radius around the traps, based on numbers of individuals caught by respective trap, and visualizes locations of the population clumps in the orchards. Colour intensity in the map represents relative density of individuals - the darker the colour, the higher the density. Particular numeric values are irrelevant in this case and not presented in this map; instead, colours should be interpreted as relative "less-more" values in this case. As organic orchard was much smaller than conventional in terms of area, different radius for calculating Kernel density was used in both orchards. For organic orchard 25 meters (as absolute majority of adult sawflies are assumed to fly as far as $25 \mathrm{~m}$ from the place of emergence according to Graf et al., 1996 b) radius around each trap position was assumed to be appropriate, as area of orchard was quite small. For conventional orchard 75 meters (farthest distance sawfly adults normally fly according to Graf et al., 1996 b) radius was used in order to render more cohesive distribution map, as scale of conventional orchard was much larger. Trap catch values were classified into different categories using Natural Breaks (Jenks) method. Natural Breaks classes are based on natural groupings inherent in the data. Class breaks are identified that best group similar values and that maximize the differences between classes. The features are divided into classes whose boundaries are set where there are relatively big differences in the data values. Based on Jenks method trap locations are represented by different colours based on the range of actual trap catch values during whole flight period in respective year of the study. All spatial analysis routines were performed using program package ARCGIS 10.

\section{Results and discussion}

In all four years, variances of overall trap catches during flight period were found to be larger than the means. It suggested that the populations were aggregated and could be adequately expressed by the negative binomial distribution. Goodness-of-fit to negative binomial was tested by the means of Kolmogorov-Smirnov test. Results of Kolmogorov-Smirnov test confirmed a good fit of trap catch data to negative binomial (Table 2). As a result, $k$ of the negative binomial serving as an index of aggregation in the populations was computed. Index $k$ allows us to estimate the extent of the aggregation - the lower the value of $k$, the higher the extent of aggregation, meanwhile, high $k$ values (approx. above 8) indicate that distribution of individuals is nearing randomness and could be described by Puasson distribution (Southwood, Henderson, 2000). Relatively small values of $k$ were obtained, indicating extensive clumping in sawfly populations. In addition, mean number of individuals in aggregation $\lambda$ was computed. This index estimates whether population is clumped due to behavioural or environmental effects. In all cases in both management systems $\lambda$ was found to be greater than 2 (Table 2), suggesting that aggregation in sawfly populations tends to be influenced at greater extent by some active behavioural patterns and at lesser extent by environment - microclimate, soil, plants, etc. (Blackith, 1958).

Table 2. Aggregation indices of apple sawfly populations in organic and conventional orchards: $k$ of negative binomial distribution and $\lambda$ - mean number of individuals in aggregation

\begin{tabular}{ccccccc}
\hline Orchard & \multicolumn{3}{c}{ Organic } & \multicolumn{3}{c}{ Conventional } \\
\hline Year & $k$ & $\lambda$ & $p^{*}$ & $k$ & $\lambda$ & $p^{*}$ \\
\hline 2010 & 2.8 & 33.9 & 0.719 & 2.0 & 15.0 & 0.062 \\
2011 & 3.0 & 3.8 & 0.940 & 2.2 & 7.6 & 0.980 \\
2012 & 4.0 & 11.3 & 0.999 & 2.2 & 3.8 & 0.999 \\
2013 & 6.0 & 5.7 & 0.988 & 2.7 & 5.3 & 0.991 \\
\hline
\end{tabular}

Note. ${ }^{*}$ - significance level of Kolmogorov-Smirnov test, used to test goodness-of-fit to negative binomial distribution.

Analysis of two-dimensional spatial distribution maps also revealed heterogeneous nature of apple sawfly populations. In both orchards, sawfly adults were localized in certain places of the orchard and the place of these clumps remained relatively constant over the course of the study independently of overall density of sawfly adults during the flight period (Figs. 4-11). In 2010, the results were influenced by the fewer number of traps deployed in the orchards, also area of both orchards differed significantly. However, despite the management system or study year $k$ and $\lambda$ values strongly indicated the aggregation of apple sawfly populations and this distribution was influenced by behavioural patterns.

In conventional orchard, judging from the location of the clumps, they were localized independently of apple cultivars or direction of rows. However, several particular areas can be specified where density of apple sawfly adults was steadily higher during all years of the study (Figs. 4-7), particularly central (even in 2012 when overall density was low) and south-eastern parts of the orchard (Fig. 6). However, there were some drawbacks in this map as trap coverage was not sufficient, especially in western part of the orchard. Nevertheless, certain trends and assumptions on sawfly population distribution patterns can be concluded based on the acquired data.

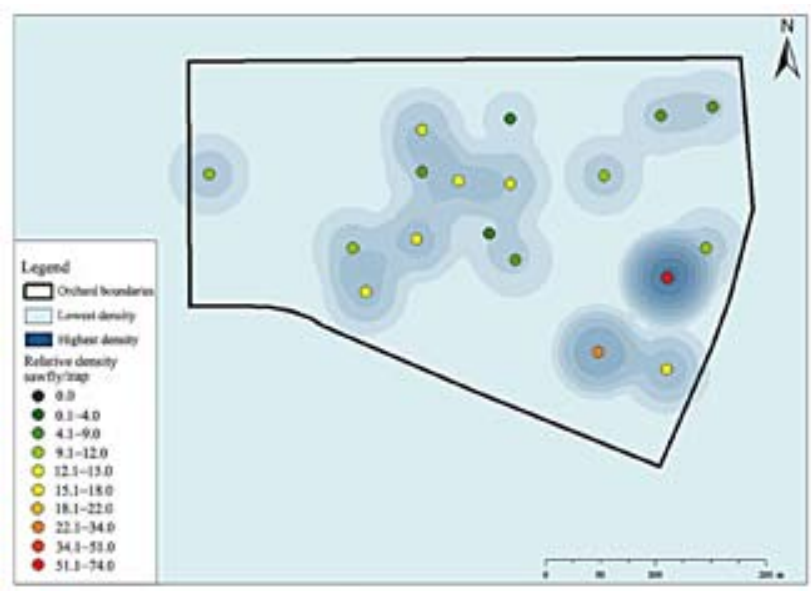

Figure 4. Spatial distribution pattern of apple sawfly adults in conventional orchard in 2010, determined by means of Kernel density function 


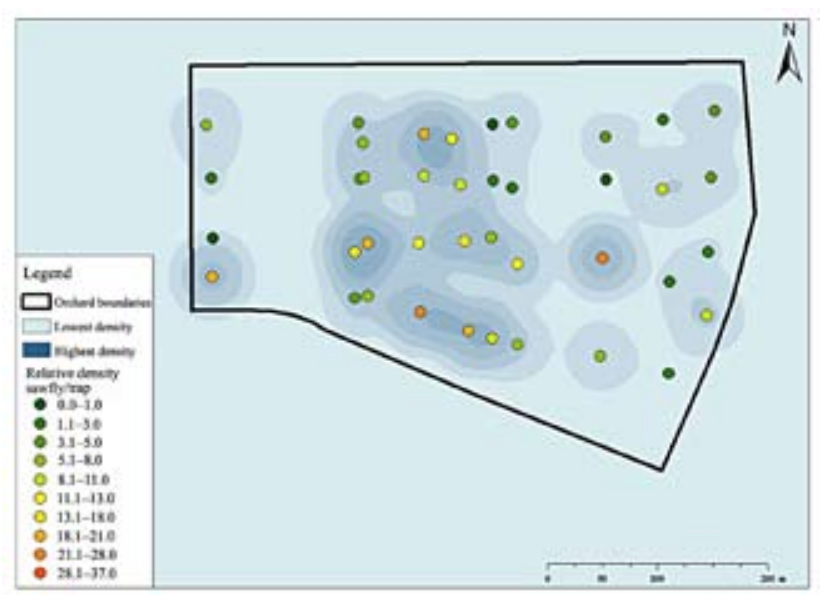

Figure 5. Spatial distribution pattern of apple sawfly adults in conventional orchard in 2011, determined by means of Kernel density function

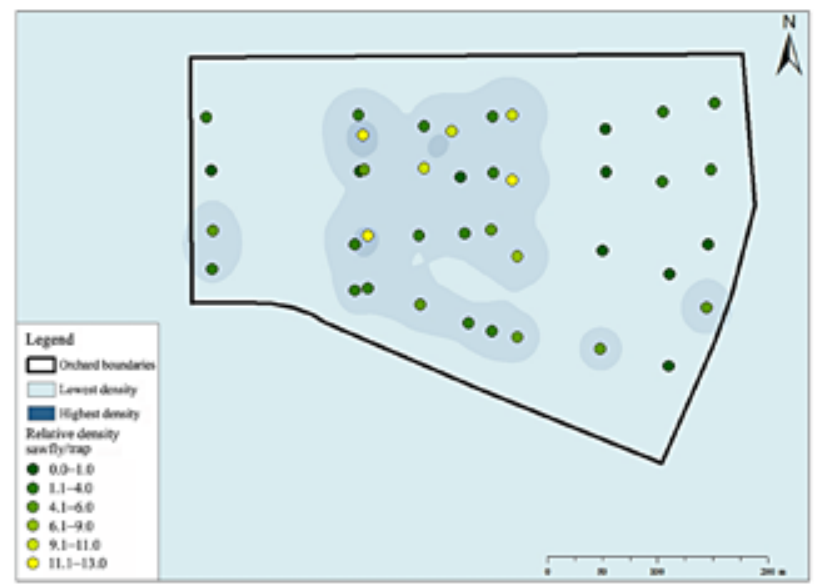

Figure 6. Spatial distribution pattern of apple sawfly adults in conventional orchard in 2012, determined by means of Kernel density function

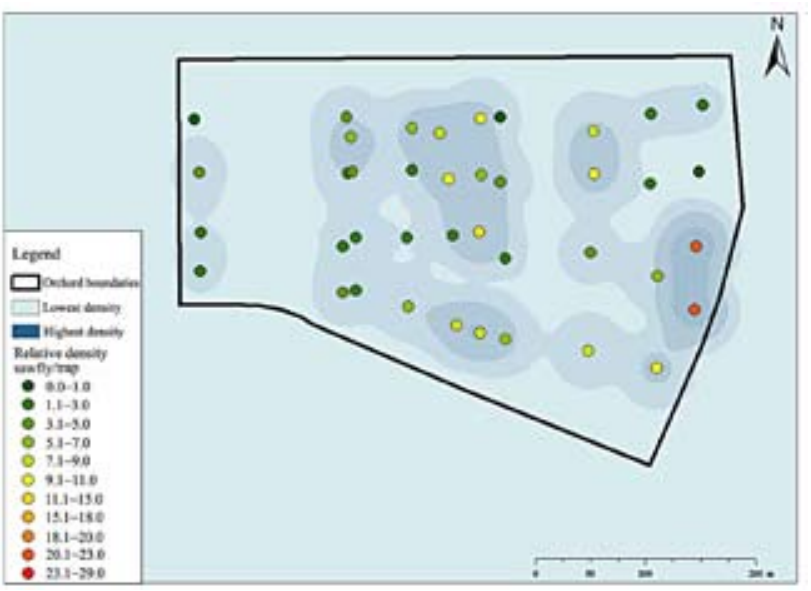

Figure 7. Spatial distribution pattern of apple sawfly adults in conventional orchard in 2013, determined by means of Kernel density function

In organic orchard, clumping of apple sawfly population was even more intensive than in conventional orchard. Over the course of the study, most intensive concentration of sawfly adults was located in the northwestern part (Figs. 8-11) and in 2012-2013 smaller aggregation was determined in the south-eastern part of the orchard (Figs. 10-11). Despite comparatively large differences between the scale of the orchards (in organic orchard distribution was investigated in significantly smaller orchard in terms of area), it could be concluded that distribution of apple sawfly adults follows a similar pattern as in conventional orchard.

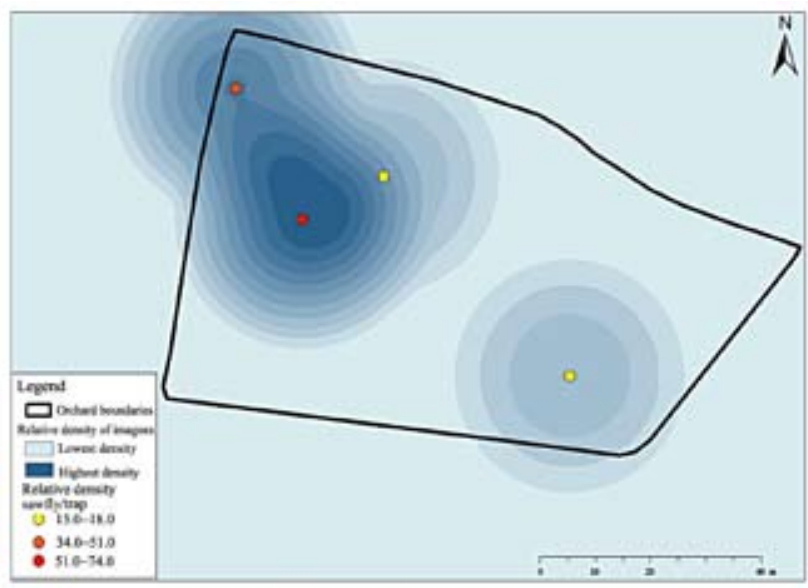

Figure 8. Spatial distribution pattern of apple sawfly adults in organic orchard in 2010 , determined by means of Kernel density function

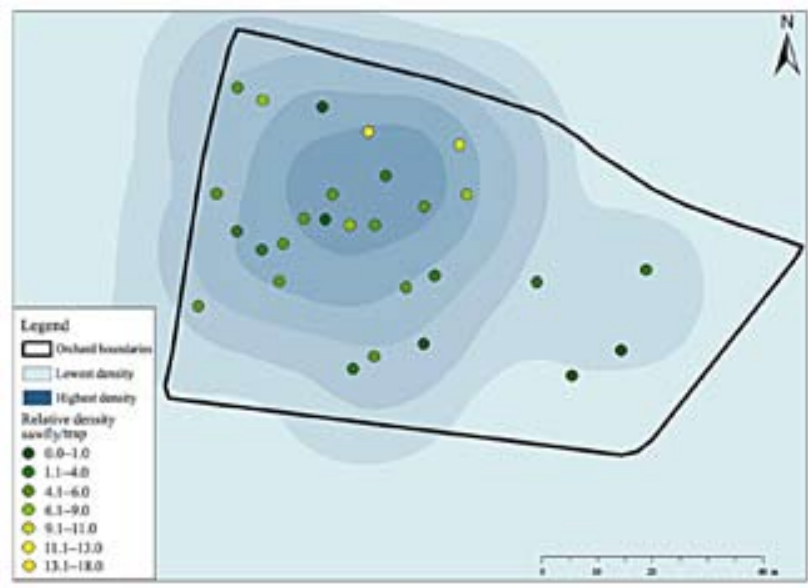

Figure 9. Spatial distribution pattern of apple sawfly adults in organic orchard in 2011, determined by means of Kernel density function

Comparing distribution patterns between orchards, the trend for clumping in particular places remained quite similar, despite different size of the orchards. At first glance, given the area of the orchard, the population in organic orchard was much more localized than in conventional. However, the radius around trap positions chosen for Kernel density analysis in organic orchard was 25 meters (as absolute majority of adult sawflies are assumed to fly as far as $25 \mathrm{~m}$ from the place of emergence according to Graf et al., 1996 b). For conventional orchard 75 meters (farthest distance sawfly adults normally fly according to Graf et al., 1996 b) radius was used in order to render more cohesive distribution map. Because of different approach in rendering distribution maps, it may seem clumping of population was significantly higher in organic orchard. Additionally, the density of the traps could have also biased the results of distribution analysis somewhat. Different radius was used to better illustrate the aggregation affinity of apple 


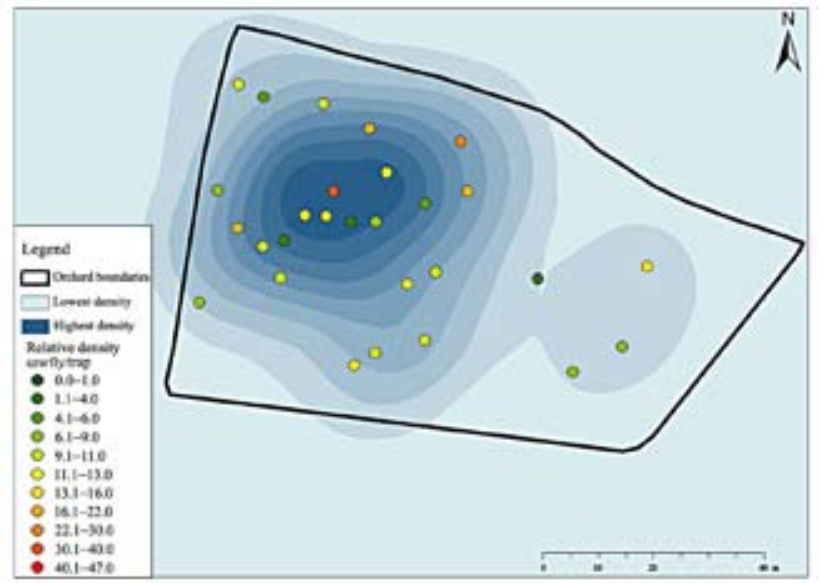

Figure 10. Spatial distribution pattern of apple sawfly adults in organic orchard in 2012, determined by means of Kernel density function

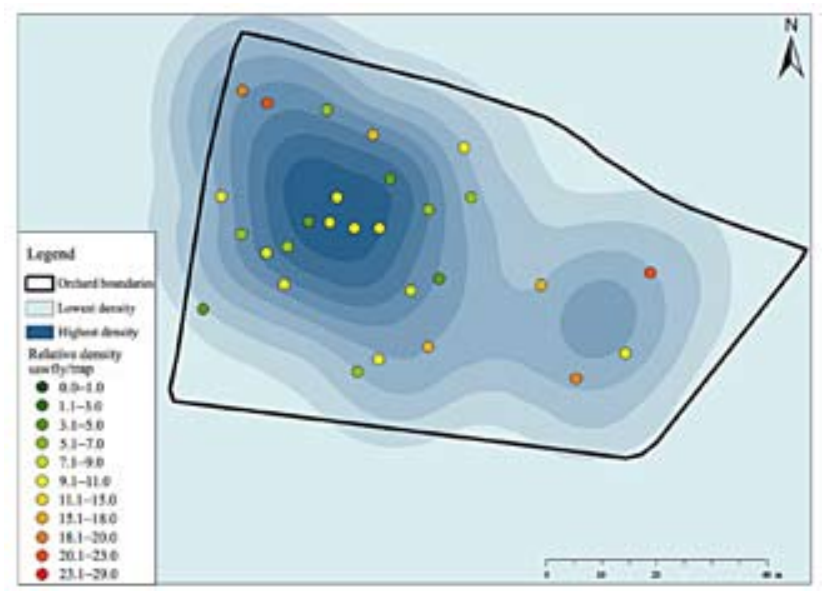

Figure 11. Spatial distribution pattern of apple sawfly adults in organic orchard in 2013 , determined by means of Kernel density function

sawfly populations. Despite differences in analysis and experimental design, the pattern of intensive clumping remained clear in both management systems.

Results of the study confirm the findings of Graf et al. (1996 b), which suggested the distribution of apple sawfly populations to be heterogeneous in orchard area and adult sawflies to be reluctant to migrate actively and to fly long distances. Most probably, apple sawfly populations are distributed in certain clumps as sawflies develop in the close vicinity to their host plants, newly emerged adults feed and oviposit on neighbouring fruittrees. Apple sawfly, along with other Hoplocampa sp. species is considered to be weak flying insects. With a relative stability of the system, i.e. for the insects that overwinter beneath perennial hosts, there appears to be little stimulus to move longer distances in order to find food source or oviposition sites (Daniel, Grunder, 2012). Flights at longer distances only occur when pests are deprived of food source or suitable blossoms for oviposition, e.g., when apple trees are skipping or flowering is very sparse and all blossoms are already with oviposited eggs (Katsoyannos et al., 1986). Flight distances of adult apple sawflies are not long as was demonstrated in mark-release-recapture experiment, performed by Graf et al. (1996 b). According to results of the experiment, $77 \%$ of adult apple sawflies were recaptured 4 meters from the release point, $97 \%-12$ meters from the release point and just several individuals were recaptured 25 meters from the place where they were released. Maximum recapture distance was 75 meters from the place of release. Of course, in extraordinary conditions flights could be performed at longer distances than normally. Flight studies in laboratory with cherry fruit fly Rhagoletis cerasi L. (Diptera, Tephritidae) which is also considered to be a weak flying species have indicated that flies are capable of flying several kilometres in $24 \mathrm{~h}$ if no landing platforms are available (Remund, Boller, 1975). Nonetheless, Graf et al. (1996 b) data have clearly indicated apple sawfly to be reluctant to fly longer distances as also has been demonstrated with cherry fruit fly where within orchards, $95 \%$ of the flies move only to neighbouring trees (Daniel, Wyss, 2009). In the case of our study, a preference towards certain apple cultivars could also play a role in spatial distribution patterns. As was demonstrated in the study by Tamošiūnas et al. (2014), certain cultivars suffered more severe infestation levels in comparison to others; however, no significant differences in sawfly numbers between cultivars were detected. Higher reproduction success or better survivability in certain cultivars may influence increase of population density and consequently, taking into account limited flying traits of apple sawfly species, aggregation around these spots. On the other hand, in conventional orchard, where sticky traps were deployed along rows of different cultivars, no clear distribution pattern, indicating a clear preference towards cultivars could be distinguished. A rootstock - cultivar combination also seemed to have no influence either on density or on infestation (Tamošiūnas et al., 2014). These results indicate more accidental nature of apple sawfly distribution in orchard territory than clearly influenced by certain apple phenotype.

\section{Conclusions}

1. Results of the study on spatial distribution patterns of apple sawfly adults demonstrated strong tendency for aggregation of adult sawflies across the orchard area which was evident in both management systems.

2. Localisation of clumps was quite constant irrespective of the size of the orchard and the type of management system.

3.Potential hotspots ofapple sawfly concentration and the highest infestation can be determined by surveying orchards for several consecutive years and providing sufficient trap coverage.

4. Knowing exact locations of aggregations could be useful for optimization of positioning of traps in the orchards and, ultimately, restricting insecticide applications only to places where they are really necessary.

\section{Acknowledgements}

The paper presents research findings, obtained through the long-term research programme "Harmful organisms in agro and forest ecosystems (KOMAS)" implemented by Lithuanian Research Centre for Agriculture and Forestry. 


\section{References}

Arbous A. G., Kerrich J. E. 1951. Accident statistics and the concept of accident-proneness. Biometrics, 7: 340-432 http://dx.doi.org/10.2307/3001656

Blackith R. E. 1958. Nearest neighbour distance measurements for the estimation of animal populations. Ecology, 39: $147-150$ http://dx.doi.org/10.2307/1929978

Carriére Y., Ellsworth P. C., Dutilleul P., Ellers-Kirk C., Barkley V., Antilla L. 2006. A GIS-based approach for areawide pest management: the scales of Lygus hesperus movements to cotton from alfalfa, weeds, and cotton. Entomologia Experimentalis et Applicata, 118 (3): 203-210 http://dx.doi.org/10.1111/j.1570-7458.2006.00384.x

Ciglar I., Barić B. 2002. Monitoring the appearance and possibility for prevention of the apple sawfly in Croatia. Journal of Pest Science, 75: 41-45 http://dx.doi.org/10.1046/j.1439-0280.2002.02013.x

Daniel C., Wyss E. 2009. Migration und Ausbreitung der Kirschfruchtfliege innerhalb von Obstanlagen Möglichkeit der biologischen Bodenbehandlung. Proceedings of the $10^{\text {th }}$ Wissenschaftstagung Ökologischer Landbau. Berlin, Germany, p. 300-301 (in German)

Daniel C., Grunder J. 2012. Integrated management of European cherry fruit fly Rhagoletis cerasi (L.): situation in Switzerland and Europe. Insects, 3: 956-988 http://dx.doi.org/10.3390/insects3040956

Falta V., Kneifl V. 2006. Scheduling pesticide treatments for controlling the apple sawfly Hoplocampa testudinea (Klug). Journal of Fruit and Ornamental Plant Research, 14 (3): 161-165

Galli P., Epp P., Harzer U., Hoehn H. 1993. Investigation on the attractivity of different white coloured traps (type REBELL and type TEMMEN) for the apple sawfly (Hoplocampa testudinea Klug). Ewerbsobstbau, 35: 91-98 (in German)

Graf B., Höhn H., Höpli H. U. 1996 (a). The apple sawfly, Hoplocampa testudinea: a temperature driven model for spring emergence of adults. Entomologia Experimentalis et Applicata, 78: 301-307

http://dx.doi.org/10.1111/j.1570-7458.1996.tb00794.x

Graf B., Höhn H., Höpli H. U. 1996 (b). Optimizing the risk assessment for the apple sawfly Hoplocampa testudinea Klug (Hymenoptera, Tenthredinidae). IOBC/WPRS Bulletin, 19: 113-117

Graf B., Höhn H., Höpli H. U. 2001. The apple sawfly, Hoplocampa testudinea: temperature effects on adult lifespan and reproduction. Entomologia Experimentalis et Applicata, 98: 377-380 http://dx.doi.org/10.1046/j.1570-7458.2001.00795.x

Graf B., Höhn H., Höpli H. U. 2002. The apple sawfly, Hoplocampa testudinea: egg development and forecasting of egg hatch. Entomologia Experimentalis et Applicata, 105: 55-60 http://dx.doi.org/10.1046/j.1570-7458.2002.01032.x

Iwao S. 1968. A new regression method for analysing the aggregation pattern of animal populations. Researches on Population Ecology, 10: 1-20 http://dx.doi.org/10.1007/BF02514729

Jumars P. A., Thistle D., Jones M. L. 1977. Detecting twodimensional spatial structure in biological data. Oecologia, 28: $109-123$ http://dx.doi.org/10.1007/BF00345246
Katsoyannos B. I., Boller E., Benz G. 1986. Das Verhalten der Kirchenfliege, Rhagoletis cerasi L., bei der Auswahl der Wirtzpflanzen und ihre Dispersion. Mitteilung der Schweizerischen entomologischen Gesellschaft, 59: 315 335 (in German)

Lloyd M. 1967. Mean crowding. Journal of Animal Ecology, 36: $1-30$ http://dx.doi.org/10.2307/3012

Racca P., Zeuner T., Jung J., Kleinhenz B. 2010. Model validation and use of geographic information systems in crop protection warning service. Oerke E. C. et al. (eds.). Precision crop protection - the challenge and use of heterogeneity. Germany, p. 259-276

Raudonis L. 1997. Harmful insect fauna in apple orchards and systems of control means to reduce its harm: summary of doctoral thesis. Lithuanian Institute of Horticulture, $32 \mathrm{p}$.

Remund U., Boller E. 1975. Qualitätskontrolle von Insekten: Messung von Flugparametern. Journal of Applied Entomology, 78 (1-4): 113-126 (in German)

Roller L., Haris A. 2008. Sawflies of the Carpathian Basin history and current research. Natura Somogyiensis 11. Kaposvár, Hungary, 261 p.

Sawyer A. J. 1989. Inconstancy of Taylor's b: simulated sampling with different quadrat sizes and spatial distributions. Researches on Population Ecology, 31: 11-24 http://dx.doi.org/10.1007/BF02515802

Southwood T. R. E., Henderson P. A. 2000. Ecological methods ( $3^{\text {rd }}$ ed.). Oxford, UK, $575 \mathrm{p}$.

Taeger A., Blank S. M., Liston A. D. 2006. European sawflies (Hymenoptera: Symphyta) - a species checklist for the countries. Blank S. M. et al. (eds.). Recent sawfly research: synthesis and prospects. Keltern, Germany, p. 399-504

Taylor L. R. 1984. Assessing and interpreting the spatial distributions of insect populations. Annual Reviews of Entomology, 29: 321-357

http://dx.doi.org/10.1146/annurev.en.29.010184.001541

Tamošiūnas R., Valiuškaitė A. 2013. The study on temperature sum model for predicting apple sawfly spring emergence and flight intensity in Lithuania. Sodininkyste ir daržininkystè, 32 (1-2): 23-37

Tamošiūnas R., Valiuškaite A., Survilienė E., Duchovskienė L., Rasiukevičiūtè N. 2014. Variety-specific population density and infestation levels of apple sawfly (Hoplocampa testudinea Klug) in two differently managed apple orchards in Lithuania. Žemdirbystè-Agriculture, 101 (2): 205-214 http://dx.doi.org/10.13080/z-a.2014.101.027

van Achterberg C. 2013. Hymenoptera. Fauna Europaea version 2.6.2 <http://www.faunaeur.org> [accessed 1609 2014]

Walczak F., Gałęzewski M., Jakubowska M., Rosiak K., Tratwal A., Złotkowski J., Heryng I., Gajewski M. 2009. Harmfulness of certain cultural crops in Poland in year 2008. Progress in Plant Protection, 49 (2): 508-528 (in Polish)

Wildbolz T., Staub A. 1984. Supervision of sawflies by checking the egg laying, the infestation and with the use of white traps. Schweizerische Zeitschrift für Obst- und Weinbau, 120: 228-232 (in German)

Zar J. H. 2010. Biostatistical analysis $\left(5^{\text {th }}\right.$ ed. $)$

Zijp J. P., Blommers L. H. M. 1997. Prediction of flight of apple sawfly, Hoplocampa testudinea, using temperature sums. Entomologia Experimentalis et Applicata, 84: 71-75 http://dx.doi.org/10.1046/j.1570-7458.1997.00199.x 
ISSN 1392-3196 / e-ISSN 2335-8947

Zemdirbyste-Agriculture, vol. 102, No. 1 (2015), p. 73-80

DOI 10.13080/z-a.2015.102.009

\title{
Obuolinio pjūklelio populiacijų erdvinis pasiskirstymas versliniuose obelų soduose
}

\author{
R. Tamošiūnas ${ }^{1}$, A. Valiuškaité1, L. Jukna², K. Tamošiūnas ${ }^{3}$, A. F. Žiogas ${ }^{4}$ \\ ${ }^{1}$ Lietuvos agrarinių ir miškų mokslų centro Sodininkystès ir daržininkystès institutas \\ ${ }^{2}$ Vilniaus universitetas \\ ${ }^{3}$ Lietuvos agrarinių ir miškų mokslų centro Žemdirbystės institutas \\ ${ }^{4}$ Aleksandro Stulginskio universiteto Biologijos ir augalų biotechnologijos institutas
}

\section{Santrauka}

Obuolinio pjūklelio (Hoplocampa testudinea Klug, 1916) populiacijų erdvinio pasiskirstymo tyrimai atlikti Lietuvos agrarinių ir miškų mokslų centro Sodininkystès ir daržininkystės instituto ekologiniame ir intensyviajame obelų soduose 2010-2013 m. Obuolinio pjūklelio suaugèlių populiacijos tankis buvo tirtas baltosiomis gaudyklėmis „Rebell ${ }^{\circledR}$ bianco“ (Andermatt Biocontrol, Šveicarija). Siekiant nustatyti sankaupos intensyvumą, buvo apskaičiuotas neigiamo binominio skirstinio koeficientas $k$ - sankaupos indeksas, taikant suderinamumo kriterijų. Koeficientas $k$ buvo nustatytas abiem sodams skirtingais tyrimo metais. Be to, siekiant tiksliau įvertinti obuolinio pjūklelio pasiskirstymo sodų teritorijose dėsningumus, buvo taikyta erdvinès analizès išsklaidytojo tankio (Kernel density) funkcija. Ši funkcija leidžia parodyti elementų tankị tam tikru spinduliu ir sodų teritorijose vizualizuoti vietas, kuriose pjūklelio suaugèlių tankis buvo didžiausias. Erdvinè analizė atlikta naudojant GIS (geografinès informacinès sistemos) programinę ịrangą ARCGIS 10. Obuolinio pjūklelio erdvinio pasiskirstymo tyrimo rezultatai atskleidè ryškią populiacijų plitimo židiniais tendenciją. Sankaupų vietos buvo gana pastovios ir erdvèje, ir tam tikru laiku, nepriklausomai nuo sodo dydžio. Tyrimo rezultatai leidžia optimizuoti obuolinio pjūklelio integruotosios kontrolès strategiją, ypač dideliuose sodų masyvuose. Sodų teritorijose išdèsčius tam tikrą kiekị gaudyklių ir atlikus kelerių metų trukmės stebėjimus, galima nustatyti kenkèjo paplitimo židinius, kuriuose galima tikètis didžiausio obuolinio pjūklelio žalingumo. Tyrimo metais abiejuose soduose daugiausia pažeistų užuomazgų buvo aptikta ant vaismedžių, esančių didžiausio pjūklelių tankio židiniuose. Be to, žinant šio kenkèjo paplitimą sodo teritorijoje, galima optimizuoti ir jo stebėseną - sode gaudykles išdèstyti tuose plotuose, kuriuose jo pasireiškimas yra labiausiai tikètinas.

Reikšminiai žodžiai: erdvinis pasiskirstymas, geografinė informacinė sistema, integruota kenkèjų kontrolè, išsklaidytasis tankis, obelų vaisių kenkèjai, obuolinis pjūklelis. 